\title{
ANALISA RANCANGAN MANAJEMEN BANDWIDTH UNTUK INFRASTRUKTUR JARINGAN KOMPUTER PADA SMK AL ALIF BLORA
}

\author{
Luluk Niken Nihayah ${ }^{1 *}$, Afis Pratama ${ }^{2}$, R.Irlanto Sudomo ${ }^{3}$ \\ MTs Al Alif ${ }^{1}$, Universitas Ivet ${ }^{2}$, Universitas Ivet ${ }^{3}$ \\ *lulukniken11@gmail.com
}

\begin{abstract}
ABSTRAK
Kebutuhan internet dalam proses pembelajaran memiliki peran yang sangat penting sehingga dalam pemakaiannya dibutuhkan pengaturan akses dan pengelolaan manajemen bandwidth yang baik demi kelancaran akses internet tersebut. Berdasarkan hasil penelitian ini adalah membutuhkan tambahan bandwidth lagi, karena kebutuhan internet dalam proses pembelajaran memiliki peran yang sangat signifikan sehingga dalam pemakaiannya dibutuhkan pengaturan akses dan pengelolaan manajemen bandwidth yang baik demi kelancaran akses internet tersebut. Tujuan dari penulisan ini Mengetahui rancangan infrastruktur jaringan di SMK Al-Alif Blora, dan Mengetahui kualitas manajemen bandwidth di SMK Al-Alif Blora.
\end{abstract}

Kata Kunci: Analisa Rancangan, Manajemen Bandwidth, Infrastruktur Jaringan Komputer.

\begin{abstract}
Need for the internet in the learning process has a very important role so that in its use it requires good access control and bandwidth management for the smoothness of internet access. Based on the results of this study, additional bandwidth is needed, because the need for the internet in the learning process has a very significant role so that in its use it requires good access control and bandwidth management for the smoothness of internet access. The purpose of this knowledge is to know the network infrastructure design at SMK Al Alif Blora, and to know the quality of bandwidth management at SMK Al Alif Blora.
\end{abstract}

Keywords: Analysis Design, Bandwidth Management, Computer Network Infrastructure.

\section{PENDAHULUAN}

Teknologi informasi juga semakin berkembang seiring dengan manusia yang mengingankan kemudahan, kecepatan dalam memperoleh informasi. Media yang digunakan untuk menyampaikan informasi bervariasi baik media cetak maupun media elektronik. Salah satu media elektronik yang paling cepat dalam menyampaikan informasi adalah melalui jaringan internet, karena penggunaan jaringan internet yang semakin pesat.

Jaringan internet adalah kumpulan komputer dan alat yang saling terhubung melalui media komunikasi dan media transmisi pada area geografis yang luas. Internet termasuk kedalam bagian jaringan komputer, dimana jaringan komputer terdiri dari jaringan local area nerwork (LAN), wide 
area network (WAN), mitropolitan area network (MAN). Dari ketiga jenis jaringan ini, jaringan komputer yang sering digunakan untuk suatu lembaga pendidikan dan intansi intansi umum lainnya ialah jaringan LAN, karena jaringan LAN adalah jaringan lokal yang hanya mencakup satu area atau satu gedung saja.

$$
\text { System manajemen bandwidth }
$$
merupakan proses pengaturan bandwidth yang tepat untuk masing-masing client pada system jaringan internet yang mendukung kebutuhan aplikasi layanan internet. Pengimplementasian manajemen bandwidth diatur melalui pengalokasian kecepatan upload dan download pada masing-masing alamat IP client secara sentralisasi menggunakan router mikrotik, yang jika ada client yang mengakses internet membutuhkan kapasitas bandwidth yang besar, maka client lain akan terganggu, karena masing-masing client sudah mempunyai kapasitas bandwidth masingmasing yang dapat dipakai untuk mengakses internet (Herlina, 2019).

Hasil observasi awal yang dilakukan di SMK Al Alif Blora banyak kendala yang dilihat, sering terjadi gangguan saat proses pembelajaran di Lab, kurangnya support jaringan internet yang ada disekolah tersebut untuk seluruh komputer yang ada di Lab, selain itu juga sering terjadi masalah dalam lambatnya konektifitas jaringan internet yang ada disekolah ketika siswa menggunakan jaringan komputer secara bersamaan di dalam Lab komputer yang menyebabkan bandwidth overload. Apabila pengguna yang lain tidak bisa masuk atau mengalami akses yang lambat,disebabkan karena keterbatasan. Dan juga dibutuhkan biaya yang mahal untuk menambah kapasitas bandwidth. Banyaknya terserang virus virus yang dapat merusak sistem, dan kurangnya pengamanan pada router disekolah SMK AL ALIF BLORA yang dimana masih banyak kelemahan seperti rentan diretas oleh hacker, dan sebagainya.

Berdasarkan latar belakang masalah yang telah dijelaskan di atas maka rumusan masalah dalam penelitian ini adalah: (1) Seperti apa rancangan infrastruktur jaringan di SMK Al Alif Blora. (2) Bagaimana kualitas manajemen bandwidth di SMK Al Alif Blora.

Penelitian ini bertujuan Mengetahui rancangan infrastruktur jaringan di SMK Al Alif Blora. (2) Mengetahui kualitas manajemen bandwidth di SMK Al Alif Blora.

Manfaat dari penelitian ini (1) Manfaat teoritis: Hasil penelitian dapat dijadikan sebagai rekomendasi untuk memberikan informasi mengenai infrastruktur jaringan yang baik khususnya dalam pengelolaan manajemen bandwidth yang tepat, Menghasilkan model manajemen bandwidth jaringan komputer yang dapat mendukung perbaikan kegiatan sekolah ,memberi kualitas yang baik, serta memberi tingkat kepuasan kepada siswa. (2) Manfaat praktis: Dapat meningkatkan optimalisasi penggunaan jaringan internet di SMK AL ALIF Blora, Dapat menambah wawasan, Dapat menjadi acuan bagi penulis, sekolah sekolah, masyarakat dan lain sebagainya.

\section{METODE PENELITIAN}

Dalam penelitian ini penulis menggunakan penelitian kulitatif yaitu penelitian yang berupa kata-kata tertulis, maupun lisan dan perilaku dari orang-orang yang diteliti. Adapun dalam penelitian penulis memfokuskan mengenai analisa rancangan manajement bandwith, sebagai berikut:

1.Fokus terhadap Analisa Rancangan Manajemen Bandwith

2.Fokus terhadap Pengelolaan Manajement bandwith. 
Metode Analisa Rancangan manajement bandwith yang akan digunakan dalam tahapan penelitian ini, akan diuraikan dalam diagram alur (flowchart) yang ditunjuk dalam gambar di bawah ini:

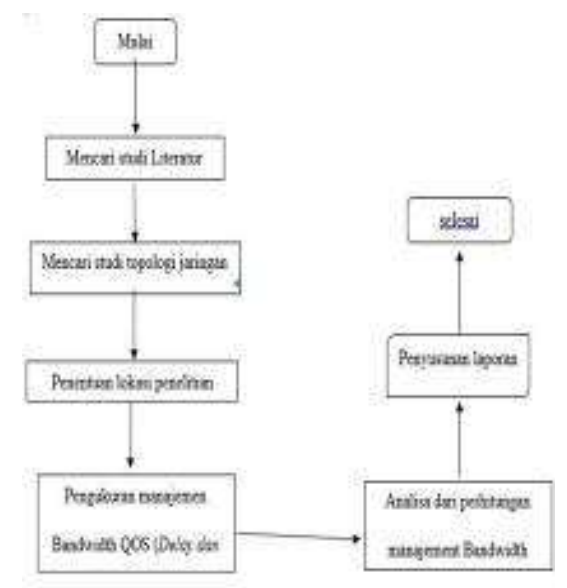

Gambar 1. Desain Penelitian

Subjek Penelitian adalah Subjek penting dalam sebuah penelitian. Informan juga diartikan orang-orang yang dimanfaatkan untuk memberikan informasi tentang situasi dan kondisi latar tempat penelitian. Sasaran penelitian adalah kepala sekolah SMK Al-Alif Blora, operasi jaringan SMK Al-Alif Blora, Operator SMK Al-Alif Blora dan siswa SMK Al-Alif Blora.

\section{Teknik pengumpulan data}

Teknik pengumpulan data merupakan langkah yang paling strategis dalam penelitian, Dalam penelitian ini penulis menggunakan metode penelitian lapangan (Field Research) penelitian lapangan yaitu sebuah metode untuk mengumpul data kualitatif dan peneliti melihat langsung ke lapangan yang ingin diteliti untuk mendapatkan pengamatan suatu fenomena adapun teknik yang digunakan antara lain.

\section{Observasi}

Observasi yaitu melakukan pengamatan langsung ke objek penelitian untuk melihat dari dekat kegiatan yang dilakukan. Objek penelitian bersifat perilaku dan tindakan manusia. Fenomena alam (kajian-kajian yang ada di alam sekitar), proses kerja dan penggunaan responden kecil. Nasution menyatakan bahwa, observasi adalah dasar semua ilmu pengetahuan. Para ilmuan hanya dapat bekerja berdasarkan data, yaitu fakta mengenai dunia kenyataan yang diperoleh melalui observasi.

\section{Wawancara}

Wawancara merupakan pertemuan dua orang untuk bertukar informasi dan ide melalui Tanya jawab, sehingga dapat dikontruksikan dalam suatu topic tertentu. Teknik wawancara yang digunakan adalah narasi karena hasil data yang diperoleh dari informan diceritakan kembali oleh peneliti.

\section{Dokumentasi}

Dokumentasi adalah suatu cara mengumpulkan data melalui peninggalan tertulis, seperti arsip, termasuk juga buku tentang teori, pendapat dalil atau hokum, dan lain-lain yang berhubungan dengan masalah penelitian. Dokumentasi yang diteliti adalah dokumen yang berupa arsip langsung tentang sekolah SMK AL-ALIF BLORA.

\section{Teknik Analisis Data}

Analisis data merupakan upaya mencari catatan hasil wawancara, observasi dan lainnya untuk meningkatkan pemahaman tentang objek penelitian.Untuk pengumpulan sebuah data kualitatif yang berhubungan dengan analisa rancangan manajemen bandwidth untuk infrastruktur jaringan computer pada SMK AL-ALIF BLORA. Teknik analisis data terdiri atas empat tahap yang harus dilakukan yaitu: (1) Tahap pengumpulan data. (2) Tahap display data.

(3) Tahap cara mengukur kualitas bandwidth, (4) Tahap penarikan kesimpulan. 


\section{HASIL DAN PEMBAHASAN}

\section{Pengelolaan Jaringan Operasional SMK Al-Alif Blora}

Permasalahan yang dihadapi dengan kemajuan teknologi informasi seperti sekarang ini, SMK Al-Alif Blora tidak mungkin lagi dapat menghindar dari penggunaan jaringa komputer. Jumlah host network yang sudaah terlalu kompleks maka perlu adanya monitoring trafik secara terpusat. Yang perlu diperhatikan adalah lingkup area komunikasi yang akan berhubungan, topologi jaringan, jenis protokol jaringan yang dipakai, serta mempersiapkan hardware network yang berkesesuaian dengan topolog dan jenis protokol yang digunakan.

SMK Al-Alif Blora pada sistem jaringan komputer untuk saat ini memakai topologi bus, namun koneksinya digabung antar wireless dan LAN. Dimana wireless di pancarakan ke laboratorium dan komputerkomputer laboratorium yang terhubung ke jaringan dengan menggunakan LAN. Kemudian providernya menggunakan speed telkomsel.

Untuk saat ini kapasitas bandwidth yang digunakan pada sistem jaringan komputer yaitu 20 mbps untuk siswa unduh sama unggahnya sebanyak 512 kbps, sedangkan untuk gurunya unduh $1 \mathrm{mb}$ dan unggah 512 kbps. Namun di SMK Al-Alif rata-rata kapasitas kecepatannya $10 \mathrm{Mbps}$. Kapasitas ini dikelola menggunakan management bandwidth, sehingga mengurangi terjadinya bandwidth overload.

Dari hasil wawancara dan observasi penelitian tentang jaringan komputer pada SMK Al Alif yaitu kebutuhan jaringan internet dalam pembelajaran sangat penting, oleh karena itu dalam pembelajaran sering menggunakan jaringan internet dan dilakukan bersama-sama sampai sering terjadinya overload pada jaringan internet, karena kurangnya bandwidth.

Manajemen bandwidth digunakan dengan membagi bandwidth sesuai dengan kelas pengguna dan melihat pada kebutuhannya sehingga tidak mengganggu aktivitas akses pengguna yang lain. Pada SMK Al-Alif Blora manajemen bandwidth yang digunakan dengan membagi limit untuk pemakaian antara guru dan siswa, agar tidak berebut bandwidth dan bandwidth menjadi overload.

Dalam jaringan komputer pada SMK Al-Alif Blora jumlah penggunaan jaringan internet itu seluruh guru dan murid. Guru jumlah sekitar 30 guru, dan murid sekitar 300 murid, tapi murid hanya di kapasitasi lab komputer.

\section{Hambatan yang dihadapi pada jaringan komputer SMK Al-Alif Blora.}

Hambatan merupakan hal yang sering menjadi keluhan bagi siswa SMK AlAlif. Hambatan dan tantangan yang terdapat pada jaringan komputer dipengaruhi oleh faktor internal dan faktor eksternal. Faktor internal umumnya berasal dari jaringan internet sendiri seperti aksesnya yang sangat lambat. Sedangkan kendala eksternal berupa putus kabel internet. Dan pengaruh dari speed telkomsel.

Selain itu, jangkauan akses yang terbatas dan kesulitan untuk mengakses dalam kapasitas besar membuat sebagian siswa terganggu terutama dalam proses belajar mengajar. Menghadapi tantangan dan rintangan yang dihadapi dalam upaya perbaikan jaringan SMK Al-Alif Blora diperlukan upgrade (tambahan) bandwidth. Karena bandwidth 20 mbps dirasa kurang maksimal untuk pengguna yang berjumlah lebih dari 1000 klien. 


\section{Analisa Rancangan Infrastruktur Jaringan Komputer Pada SMK Al- Alif Blora.}

Rancangan jaringan pada SMK AlAlif Blora sebuah 2 router dan 1 server yang digunakan sebagai interface untuk jaringan.

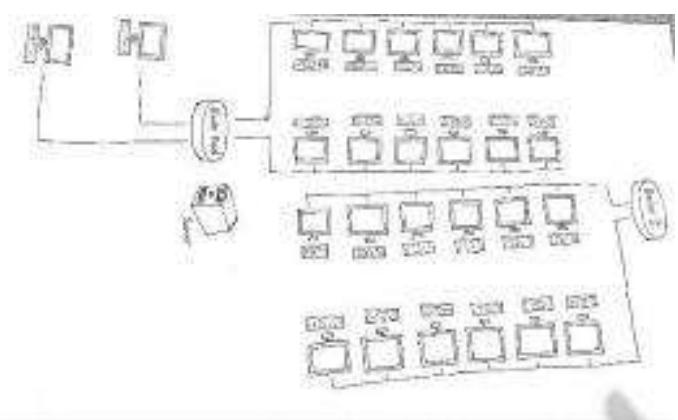

Gambar 4.1 Rancangan jaringan komputer SMK AlAlif Blora

Dari gambar di atas dapat dijelaskan bahwa pada SMK Al-Alif Blora memiliki 2 perangkat jaringan Wireless dan Lan. Dimana wireless dipancarkan dan terhubung ke setiap Lab komputer. Lab pemasaran dan lab listrik. Disetiap lab mengunakan perangkat LAN (local area network) terhubung ke internet.

Pada SMK Al-Alif Blora pembagian bandwidth yang dimiliki hanya up to $10 \mathrm{mbps}$ menggunakan metode statik yaitu pada setiap user di berikan batas limit tertentu, pada SMK Al-Alif Blora user dibagi menjadi 2 yaitu guru dan siswa, dimana pada guru diberikan bandwidth sebanyak 9.17 mbps untuk unduh, sedangkan siswa diberikan bandwidth sebanyak 8.99 mbps untuk unduh dan 0.70 mbps untuk unggah.

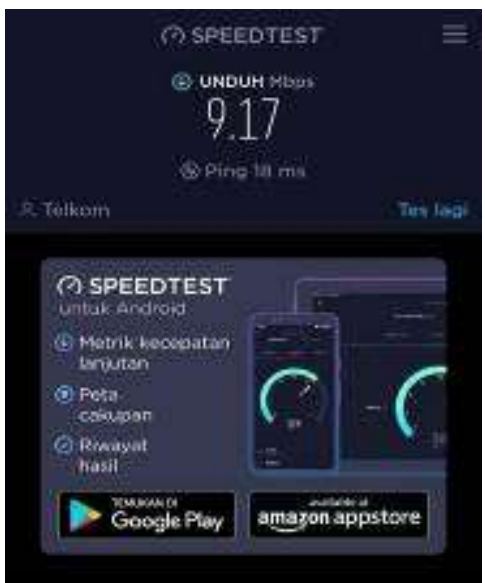

Gambar 2. Test kecepatan jaringan pada jaringan guru

Pada gambar 4.2 di atas dapat dijelaskan bahwa pengelolaan bandwidth tanpa menggunakan batas limit akan mengalami penggunaan bandwidth mencapai 9.17 mbps untuk unduh pada setiap user yang login pada jaringan internet di SMK Al-Alif Blora, dan dengan demikian dapat menyebabkan pemakaian bandwidth yang berlebihan atau bandwidth overload.

Gambar di atas menunjukan kecepatan 9.17 Mbps karena terjadinya troubel pada jaringan tersebut, user menggunakan jaringan yang banyak dan ratarata dalam kecepatan jaringan internet 10 Mbps.

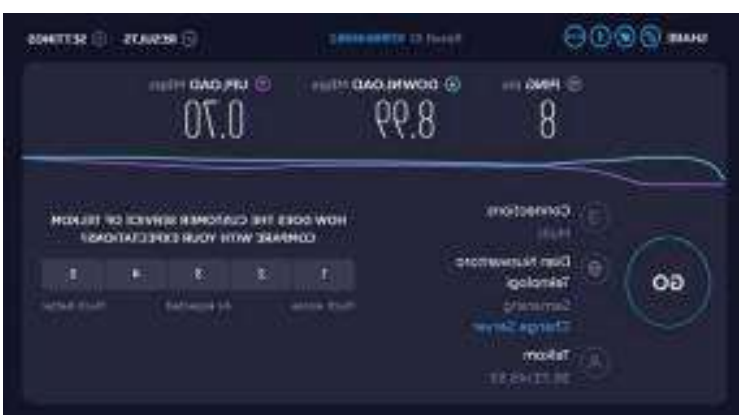

Gambar 3. Test pada kecepatan jaringan pada jaringan murid 
Dari gambar 4.3 di atas dapat dijelaskan bahwa pengelolaan bandwidth dengan tanpa menggunakan batas limit 8.99 mbps untuk unduh dan 0.70 mbps untuk unggah pada setiap user yang login pada jaringan internet di SMK Al-Alif Blora, dan dengan demikian dapat menyebabkan pemakaian bandwidth yang berlebihan atau bandwidth overload.

\section{Pengecekan kinerja/kualitas jaringan dalam pengelolaan manajemen bandwidth.}

Perhitungan analisa manajemen bandwidth (delay dan throghtput) dihitung menggunakan aplikasi wireshark (versi 2.6.5) untuk rancangan komputer pada SMK Al-Alif Blora sebagai berikut:

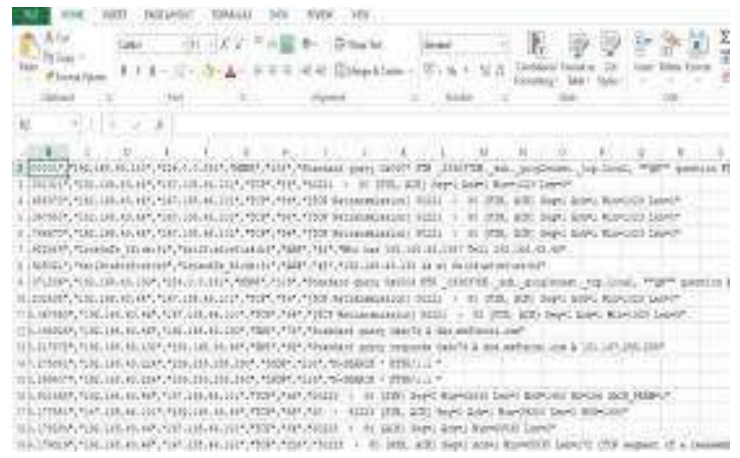

Gambar 4.6 jaringan yang digunakan menggunakan aplikasi wireshark

a. Delay

Hasil perhitungan delay dengan aplikasi wireshark (versi 2.6.5) adalah sebesar -3469,55 ms. Dimana jika dilihat dari tabel standarisasi pemakaian delay yang bersumber dari TIPHON, jika nilai pemakaian delay nya kurang dari $<150 \mathrm{~ms}$ maka pemakaian delay termasuk kedalam kategori sangat baik.

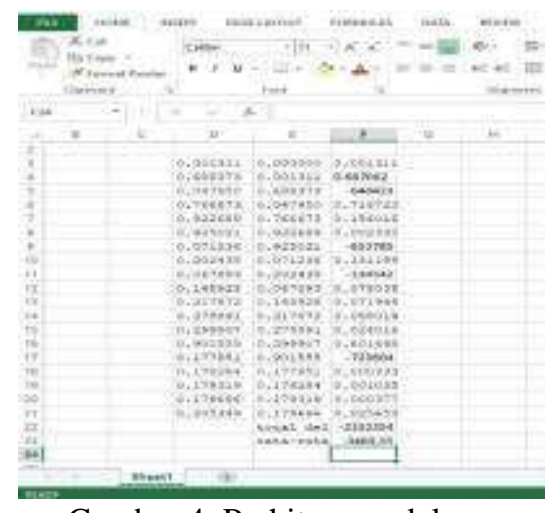

Gambar 4. Perhitungan delay

b. Throughput

Hasil perhitungan throughput menggunakan aplikasi wireshark (versi 2.6.5) untuk perancangan jaringan komputer pada SMK Al-Alif Blora adalah sebesar 0.51219837355 Mbit/sec.

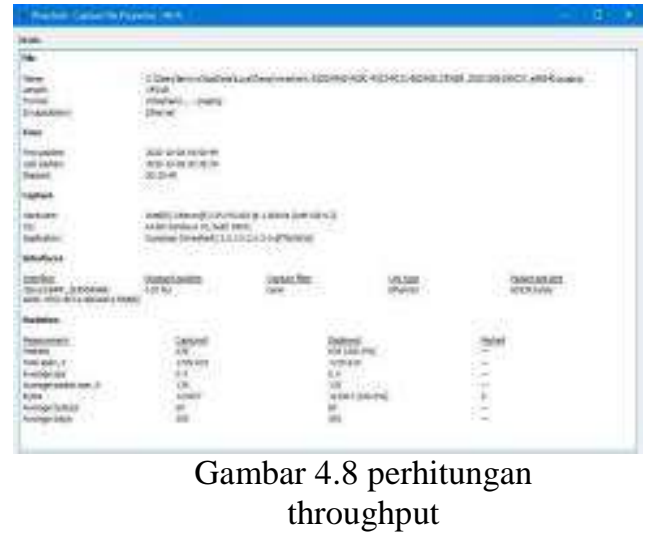

KESIMPULAN

SMK Al-Alif Blora sering mengalami bandwidth overload dan lambatnya konektivitas karena kurangnya pengelolaan pada manajemen bandwidth. Setelah dilakukan pengujian menggunakan situs speedtest dan aplikasi wireshark (versi 2.6.5) pada SMK Al-Alif Blora dimana diperoleh perhitungan delay dan thourghput terdapat signifikan perancangan manajemen bandwidth untuk jaringan komputer karena memiliki pemakaian delay yang sangat baikyaitu $<150 \mathrm{~ms}$. Sedangkan thourghput pada jaringan komputer bagus karena rancangan 
komputer memperoleh rata-rata sebesar 0,51219837355 Mbit/sec.

\section{SARAN}

Adapun saran-saran yang dapat penulis sampaikan berdasarkan hasil yang diperoleh dari penelitian ini adalah: (1) Diharapkan untuk pihak sekolah menambahkan kapasitas bandwidthnya, agar koneksi internet tidak terlalu lambat jika dibagi kebanyak user. (2) Diharapkan adanya pengawasan dari operator jaringan untuk mengontrol aktifitas klien-klien khususnya siswa dalam mengakses jaringan internet. (3) bagi peneliti selanjutnya agar dapat mengkaji lebih dalam lagi mengenai penelitian ini tentang analisa rancanngan manajemen bandwidth untuk infrastruktur jaringan komputer agar lebih efektif dalam mengelola manajemen bandwidth yang tepat pada setiap jaringan komputer.

\section{DAFTAR PUSTAKA}

Djamen, A. C. (2017). Analisis Dan Perancangan Infrastruktur Jaringan Komputer Studi Kasus: Fakultas Teknik Universitas Negeri

Manado. Engineering Education Journal (E2J-UNIMA), 1-6.

Herlina, E. (2019). Analisa Rancangan Manajemen Bandwidth Untuk Infrastruktur Jaringan Komputer Pada SMKN 1 ABDYA. peran teknologi informasi dalam pendidikan. skripsi Univ islam negeri ar-raniry darussalam-bandan aceh, 11-23.

Syukur, A. (2018). Analisis Management Bandwidth Menggunakan Metode Per Connection Queue (PCQ) dengan Authentikasi RADIUS . IT Journal Research and Development 78-89.

Hidakyah, M. (2010). Analisa Dan Perancangan Manajemen Jaringan Dengan Mikrotik Routeros. Jurnal teknik informatika, 1-20. 